\title{
Hubungan Indeks Masa Tubuh (IMT) dengan Persen Lemak Tubuh, dan Lemak Viscelar di Kota Semarang
}

\section{Purwanti Susantini}

Fakultas Ilmu Keperawatan dan Kesehatan Universitas Muhammadiyah Semarang purwanti@unimus.ac.id

\begin{abstract}
Indonesia is predicted to experience a demographic bonus period, namely the number of productive age population (aged 15-64 years) of 64\%. The prevalence of obesity at productive age from 2007 to 2018 has increased from 8.6\% to 13.6\%. Obesity will result in high percent body fat and visellar fat, and will result in various non-communicable diseases such as type 2 diabetes, cardiovascular disease, stroke, cancer and other non-metabolic complications such as arthritis. The onset of this disease in obese people is preceded by a group of symptoms such as hypertension, insulin resistance, dyslipidemia. Objectives: To determine the relationship between Body Mass Index and Percent body fat and to determine the relationship between Body Mass Index and Viscelar Fat. Methods: This study used a cross sectional design with purposive sampling method, namely those visiting the Aisyiyah Regional Leadership Stand in Semarang City at the Expo of Community Organizations in Semarang City. The sample is 115 people. Results: This study found that 35 (30.4\%) men and 80 (69.6\%) women, Average Age: (45.14 \pm 14.55$)$ years, Body Mass Index (25.39 \pm 3.96$)$, mean percent body fat $(32.63 \pm 6.68)$ mean viscelar fat $(7.93 \pm 5.13)$. There is a relationship between $B M I$ and percent body fat $(p=0.000)$ and there is a relationship between BMI and Viscelar fat $(p=$ 0.000).
\end{abstract}

Keywords: Body Mass Index, percent body fat, Viscelar fat 


\section{PENDAHULUAN}

Pembangunan kesehatan sebagai mana dalam Sistem Kesehatan Nasional merupakan upaya yang dilaksanakan oleh semua komponen Bangsa Indonesia. Tujuannya untuk meningkatkan kesadaran, kemauan, dan kemampuan hidup sehat bagi setiap orang agar terwujud derajat kesehatan masyarakat yang setinggi-tingginya. Pembangunan kesehatan sebagai investasi bagi pembangunan sumber daya manusia yang produktif secara sosial dan ekonomis. Saat ini Indonesia mengalami beban ganda, yaitu masalah penyakit menular yang belum tuntas, dan muncul penyakit tidak menular menular terjadi peningkatan yang signifikan. (Kementrian Kesehatan, 2020). Hasil Riskesdas tahun 2018 bahwa angka prevalensi diabet melitus, hipertensi, jantung, obesitas pada usia diatas 15 tahun mengalami peningkatan dibandingkan pada tahun 2013. Prevalensi diabet untuk usia lebih dari 15 tahun, pada tahun 2013 sebesar 6,9\% naik menjadi 8,5\% pada tahun 2018 . Prevalensi hipertensi berdasarkan pengukuran tekanan darah pada usia diatas 18 tahun, pada tahun 2013 sebanyak 25,8\% naik menjadi $34,1 \%$. Prevalensi stroke pada tahun 2013 sebesar $7 \%$ naik menjadi 10,9 $\%$. Prevalensi Obesitas juga mengalami kenaikan dari tahun 2007 sampai 2018, yaitu dengan IMT $25-<27$ pada tahun 2007 dari $8,6 \%$, naik menjadi $11,5 \%$ pada 2013 , dan pada tahun 2018 naik menjadi sebesar 13,6
\%. Prevalensi Obesitas dengan IMT $>=27$ pada tahun 2007 sebesar 10,5\%, menjadi 14,8 \% pada tahun 2013 dan pada tahun 2018 menjadi 21,8\%. Obesitas sentral juga mengalami kenaikan, pada tahun 2007 sebesar 10,8\%, tahun 2013 sebesar 26,6\% dan 2018 sebesar 31,8 \%.(Kementrian Kesehatan, 2019, Bappenas, 2017) Pada tahun 2030 - 2040, jumlah penduduk yang diproyeksikan sebesar 297 ribu jiwa, dan 64 $\%$ merupakan usia produktif. Hal ini tentunya menjadi tantangan agar usia produktif tersebut dapat dioptimalkan salah satunya dalam keadaan sehat.

Obesitas merupakan masalah kesehatan yang sifatnya kronis. Peningkatan prevalensi obsitas tidak hanya di Indonesia, tetapi juga pada negara negara di dunia. Dari beberapa penelitian terbukti bahwa obesitas dapat mengakibatkan berbagai penyakit tidak menular seperti diabet Melitus tipe 2, kardiovaskuler, stroke, kanker dan komplikasi non-metabolik lainnya seperti artrithis (Wiardani, dkk 2014). Semakin tinggi IMT akan meningkatkan persen massa lemak dan lemak viscelar 'Fatimah' dkk 2017). Lemak viseral juga akan mempengaruhi besar lingkar perut sehingga semakin tinggi persen lemak viseral akan semakin meningkatkan risiko mengalami obesitas sentral (Fatimah, dkk 2017, Sofa, 2018).

Penelitian ini bertujuan untuk 
mengetahui hubungan antara Indeks Masa Tubuh dengan Persen lemak tubuh dan mengetahui hubungan antara Ideks Masa Tubuh dengan Lemak Viscelar.

\section{METODE PENELITIAN}

Penelitian ini dilakukan di Kota Semarang pada saat ada kegiatan Expo Organisasi Masyarakat se Kota Semarang. Pimpinan Daerah Aisyiyah Kota Semarang salah Organisasi Masyarakat mengikuti expo dengan membuka stand. Kegiatan yang dilakukan di stand PDA Aisyiyah saat expo antara lain pengukuran berat badan, Indeks Masa Tubuh (IMT), lemak tubuh dan lemak viseral. Rancangan penelitian cross sectional dengan cara survei. Pengambilan sampel secara purposive yaitu para pengunjung yang singgah di stand Pimpinan Daerah Aisyiyah Kota Semarang dan bersedia diukur. Jumlah sampel sebanyak 115 orang. Data primer yang diambil meliputi pengukuran berat badan, Indek Masa Tubuh (IMT), lemak tubuh (Body Fat) dan lemak viseral (Viscelar Fat). Alat yang digunakan untuk pengukuran menggunakan alat "Body Composition Monitor" dengan ketelitian $0,1 \mathrm{~kg}$. Pengolahan data umur dikategorikan remaja yaitu untuk umur $<21$ tahun, dewasa umur 22 tahun -44 tahun, pra lansia 45 tahun -60 tahun, dan lansia > 60 tahun. Indek Masa Tubuh dikategorikan menurut WHO 2013, yaitu Berat Badan kurang jika nilai IMT < $18,5 \mathrm{~kg} / \mathrm{m}^{2}$, Normal jika $18,5-<25 \mathrm{~kg} / \mathrm{m}^{2}$, Jurnal Gizi Unimus Vol 10 No 12021 berat badan berlebih jika $25-30 \mathrm{~kg} \cdot \mathrm{m}^{2}$. dan obesitas jika IMT > $30 \mathrm{~kg} / \mathrm{m}^{2}$. Data persen lemak tubuh dikategorikan; untuk wanita kategori sangat tinggi: $\geq 35 \%$, Tinggi jika $30 \%-<35 \%$, normal jika $20 \%-<30 \%$, rendah jika $<20 \%$. Kategori Lemak tubuh pada pria sangat tinggi jika nilainya $\geq 25 \%$, Tinggi jika $20 \%-25 \%$, normal jika $10 \%$ $<20 \%$ rendah jika $<10 \%$. Lemak Viscelar dikategorikan normal 0,5 - 9,5, tinggi $10-$ 14,5 dan sangat tinggi $15-30$.

\section{HASIL DAN PEMBAHASAN}

\section{Karakteristik Sampel}

Karakteristik sampel berdasarkan jenis kelamin, pekerjaan dan umur dapat dilihat pada tabel 1. Berdasarkan tabel 1 diatas, responden dalam survei ini sebagian besar berjenis kelamin wanita yaitu sebanyak 80 orang $(69,6 \%)$, Usia remaja akhir 6 orang $(5,2 \%)$, Usia dewasa yang berumur $22-44$ tahun dan usia pra lansia masing masing sebanyak 47 orang 40,9\%, dan usia lansia diatas 60 th sebanyak 15 orang (13\%). Sebagian besar sampel merupakan usia produktif, dari kelompok lansia 10 orang $(8,7 \%)$ merupakan kelompok tidak produktif karena usianya sudah di atas 64 tahun. Usia produktif ini diharapkan dalam keadaan sehat, sehingga dapat menjalankan kehidupannya dengan baik, tidak menjadi beban keluarga maupun negara. 
Tabel 1. Karakteristik Responden Berdasarkan Jenis Kelamin, Umur dan Pekerjaan.

\begin{tabular}{lcc}
\hline \multicolumn{1}{c}{ Karakteristik } & n & \% \\
\hline Jenis Kelamin & & \\
- Laki -laki & 35 & 30,4 \\
- Perempuan & 80 & 69,6 \\
Umur & & \\
- $\leq 21$ tahun & 6 & 5,2 \\
- 22-44 tahun & 47 & 40,9 \\
- 45-59 tahun & 47 & 40,9 \\
- >60 tahun & 15 & 13,0 \\
Pekerjaan & & \\
- Buruh & 9 & 7,8 \\
- IRT & 35 & 30,4 \\
- Mahasiswa & 6 & 5,2 \\
- Pedagang & 8 & 7 \\
- Pensiunan & 10 & 8,7 \\
- PNS & 16 & 13,9 \\
- Swasta & 31 & 27 \\
\hline
\end{tabular}

Pekerjaan responden 35 orang (30,4

$\%)$ sebagai ibu rumah tangga, karena jumlah responden sebagian besar wanita, dimana seorang ibu tidak berkewajiban mencari nafkah untuk kelangsungan hidup keluarga, tetapi peran wanita sangat besar untuk pembangunan sebagaimana dalam Undang Undang No. 6 tahun 2014 tentang Desa peran perempuan yang sangat diperlukan untuk keberhasilan Pembangunan, baik di perkotaan maupun pedesaan. Peran perempuan terutama dalam menangani berbagai masalah sosial ekonomi yang diarahkan pada pemerataan hasil pembangunan, pengembangan sumberdaya manusia yang berkualitas dan pemeliharaan lingkungan (Zahrok, 2020).

\section{Distribusi IMT, Persen Lemak Tubuh} dan Lemak Viscelar

Indeks Masa tubuh kategori berat badan berlebih dan obesitas masing-masing $18,3 \%$ dan $32,2 \%$. Jumlah tersebut lebih tinggi dengan hasil Riskesdas 2018 nilai IMT $25-<27$ atau kelebihan berat badan sebanyak 13,6 \% dan nilai IMT > 27 sebanyak $21,8 \%$. Hal ini dapat dilihat pada Tabel 2, dibawah ini

Tabel 2. Distribusi Sampel berdasarkan IMT, Persen Lemak Tubuh dan Lemak Viscelar

\begin{tabular}{lcc}
\hline \multicolumn{1}{c}{ Kategori } & Jumlah & $\%$ \\
\hline IMT & & \\
- Kurus & 3 & 2,6 \\
- Normal & 54 & 47,0 \\
- Berat badan berlebih & 21 & 18,3 \\
- Obesitas & 37 & 32,2 \\
Persen Lemak Tubuh & & \\
- Rendah & 1 & 0,9 \\
- Normal & 21 & 18,3 \\
- Tinggi & 30 & 26,1 \\
- Sangat tinggi & 63 & 54,8 \\
Lemak Viscelar & & \\
- Normal & 84 & 73 \\
- Tinggi & 21 & 18,3 \\
- Sangat tinggi & 10 & 8,7 \\
\hline
\end{tabular}

Persen lemak tubuh dengan kategori tinggi dan sangat tinggi cukup banyak yaitu masing-masing $26,1 \%$ dan $54,8 \%$. Lemak dalam tubuh adalah lipoprotein yang mengandung trigliserid, fosfolipid dan kolesterol yang bergabung dengan protein. Jenis yang ada pada tubuh adalah High Density Lipoprotein (HDL), Low Density Liproprotein (LDL), Veri Low Density Lipoprotein (VLDL), dan glikolipid. Peningkatan kadar kolesterol LDL dan trigliserid serta penurunan kolesterol HDL serta ada faktor risko seperti merokok, hipertensi dapat menyebabkan Atherosclerotic Cardiovasoscular Disease 
(ASCD) (Fatimah, dkk 2017)

Hasil survei ini didapatkan responden yang mempunyai lemak viscelar tinggi sebanyak 18,3\% dan yang sangat tinggi sebanyak 8,7 \%. Lemak viseral merupakan lemak tubuh yang terkumpul di bagian sentral tubuh dan melingkupi organ internal. Kelebihan lemak viseral berhubungan erat dengan peningkatan risiko penyakit kardiovaskuler , sindrom metabolik (hipertensi, dislipidemia, dan diabetes tipe II), dan resistensi insulin. Suatu penelitian menyatakan bahwa seseorang yang mengalami obesitas cenderung memiliki lemak viseral tubuh yang berlebih. Lemak viseral dapat juga mempengaruhi besar lingkar perut sehingga semakin tinggi persen lemak viseral akan semakin meningkatkan risiko mengalami obesitas sentral (Sofa, 2018).

\section{Rata-rata Usia, IMT. Persen Lemak} Tubuh dan Lemak Viscelar

Rata-rata Usia sampel $(45,14 \quad \pm$ 14,55) tahun terdiri usia remaja sampai lansia. Rata-rata Nilai IMT $(25,39 \pm 3,96)$, rata-rata Persen lemak tubuh $(32,63 \pm 6,68)$ sehingga dalam kategori tinggi, dan rata-rata lemak viscelar $(7,93 \pm 5,13)$. Dapat dilihat pada tabel 3 dibawah ini :
Tabel 3. Nilai Rata-rata Usia, IMT, Persen Lemak dan Lemak Viscelar

\begin{tabular}{lccccc}
\hline & $\mathrm{n}$ & Min & Max & Rata & SD \\
\hline Umur & 115 & 19,00 & 76,00 & 45,1 & 14,55 \\
\hline IMT & 115 & 17,60 & 37,20 & 25,39 & 3,96 \\
\hline $\begin{array}{l}\text { Persen } \\
\text { Lemak }\end{array}$ & 115 & 13,00 & 46,90 & 32,63 & 6,69 \\
$\begin{array}{l}\text { Lemak } \\
\text { Viscelar }\end{array}$ & 115 & 0,5 & 35,00 & 7,93 & 5,13 \\
\hline
\end{tabular}

\section{Hubungan IMT dengan Persen lemak tubuh}

Lemak tubuh terbagi menjadi dua yaitu lemak esensial dan lemak cadangan. Lemak esensial merupakan lemak yang digunakan dalam fungsi fisiolois sehari-hari dan berada pada bagian organ-organ tubuh seperti jantung, ati, ginjal, paru-paru, serta jaringan sistem saraf pusat yang terdiri dari banyak lemak. Lemak cadangan adalah lemak yang terbentuk dalam jaringan adiposa yang melindungi organ-organ tubuh yang terletak di bawah kulit (subkutan).

5. Hubungan IMT dengan Persen lemak Tubuh

Tabel 4. Persen Lemak Tubuh Berdasarkan Indeks Masa Tubuh

\begin{tabular}{|c|c|c|c|c|c|}
\hline \multirow[t]{2}{*}{ IMT } & \multicolumn{4}{|c|}{ \% Lemak Tubuh } & \multirow[t]{2}{*}{ Total } \\
\hline & $\mathrm{R}$ & $\mathrm{N}$ & $\mathrm{T}$ & ST & \\
\hline \multirow[t]{2}{*}{ Rendah } & 0 & 1 & 1 & 1 & 3 \\
\hline & $0,0 \%$ & $33,3 \%$ & $33,3 \%$ & $33,3 \%$ & $100 \%$ \\
\hline \multirow[t]{2}{*}{ Normal } & 1 & 18 & 17 & 18 & 54100 \\
\hline & $1,9 \%$ & $33,3 \%$ & $31,5 \%$ & $33,3 \%$ & $\%$ \\
\hline \multirow{2}{*}{$\begin{array}{l}\text { Over- } \\
\text { weight }\end{array}$} & 0 & 0 & 8 & 13 & 21100 \\
\hline & $0,0 \%$ & $0,0 \%$ & $38,1 \%$ & $61,9 \%$ & $\%$ \\
\hline \multirow[t]{2}{*}{ Obesitas } & 0 & 2 & 4 & 31 & 37100 \\
\hline & $0,0 \%$ & $5,4 \%$ & $10,8 \%$ & $83,8 \%$ & $\%$ \\
\hline \multirow[t]{2}{*}{ Total } & 1 & 21 & 30 & 63 & 115 \\
\hline & $0,9 \%$ & $18,3 \%$ & $26,1 \%$ & $54,8 \%$ & $100 \%$ \\
\hline
\end{tabular}


Berdasarkan uji korelasi pearson didapat ada hubungan antara Indek Masa Tubuh dengan persen lemak $(\mathrm{p}=0,000)$, hal ini sesuai dengan hasil penelitian Siti Nur Fatimah, Ieva B Akbar, Ambrosius Purba, Vita Murniati Tarawan, Gaga Irawan Nugraha, Putri Tessa Radhiyanti, dan Titing Nurhaya, bahwa Koefisien bernilai positif artinya terdapat hubungan positif antara nilai IMT dengan persen massa lemak, semakin tinggi IMT akan meningkatkan persen massa lemak. Oleh karena itu terdapat kesetaraan kenaikan IMT dengan pemeriksaan massa lemak berdasarkan tebal lemak subkutan, sehingga IMT relevan dipakai untuk memprediksi massa lemak tubuh(Fatimah' dkk 2017). IMT tidak mengukur lemak tubuh secara langsung, tetapi penelitian menunjukkan bahwa IMT berkorelasi dengan pengukuran secara langsung lemak tubuh seperti under water weighing dan dual energy $\mathrm{X}$-ray absorbtiometry. IMT merupakan altenatif untuk tindakan pengukuran lemak tubuh karena murah serta metode skrining kategori berat badan yang mudah dilakukan. Perhitungan analisis, didapatkan nilai konstanta konstanta 2,757, koefisien regresi IMT 0,089 artinya setiap peningkatan 1 IMT akan meningkatkan persen massa lemak sebesar $(2,757+$ $\left.1^{*} 0,089\right)$. Koefisien bernilai positif artinya terdapat hubungan positif antara nilai IMT dengan persen massa lemak, semakin tinggi IMT akan meningkatkan persen massa lemak. Implikasi persamaan ini memperlihatkan terdapat kesetaraan kenaikan IMT dengan pemeriksaan massa lemak berdasarkan tebal lemak subkutan, sehingga IMT relevan dipakai untuk memprediksi massa lemak tubuh (Nurmalasari, 2017).

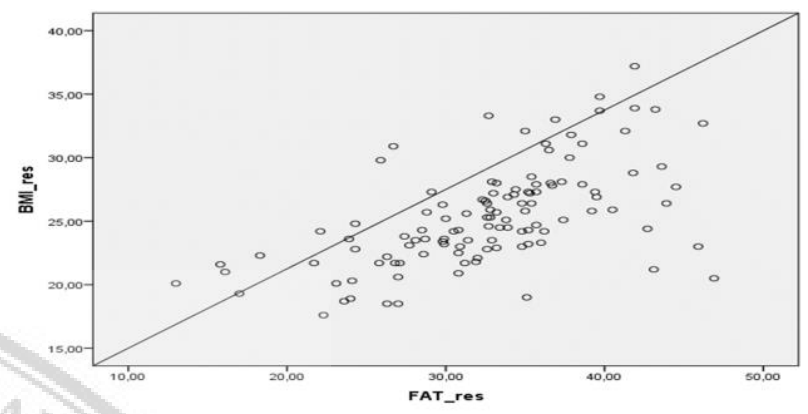

Gambar 1. Hubungan IMT dengan persen lemak tubuh. Massa lemak berlebih berhubungan dengan berbagai risiko penyakit karena lemak berlebih akan mengganggu kontrol axis hipotalamuspituitary, mempengaruhi lemak viseral dan lemak sirkulasi, mengganggu aktivitas berbagai regulator seperti enzim dan hormon, mempengaruhi berbagai mediator antara seperti meningkatnya sitokin proinflamasi. Kondisi tersebut menyebabkan inflamasi kronis dan secara kumulatif akan menurunkan fungsi organ.

Kegemukan sering berhubungan dengan peningkatan trigliserida, kolesterol total, LDL serta penurunan kadar HDL. Distribusi lemak regional mempunyai pengaruh penting terhadap faktor risiko penyakit metabolik dan kardiovaskular. Peningkatan akumulasi lemak visceral 
adalah faktor risiko terhadap coronaryartery disease (CAD), hipertensi, stroke dan type 2 Hasil dari penelitian Kurniawan , Liong Boy, dkk menunjukkan bahwa lima indeks obesitas, Berat badan, Indeks Masa Tubuh, Lingkar Pinggang, Persen lemak tubuh, lemak viscelar semua mempunyai korelasi yang significan dengan resisten insulin. Obesitas dikaitkan dengan beberapa gangguan metabolisme termasuk resistensi insulin (IR) dan diabetes mellitus (DM). Kegemukan menginduksi pengembangan IR melalui beberapa mekanisme. IR adalah faktor predisposisi untuk perkembangan DM dan sindrom metabolic (Liong, dkk, 2018).

Hasil penelitian ini menunjukkan bahwa indeks obesitas dari pengukuran Indek Masa Tubuh dan lingkar pinggang dan persen lemak tubuh dapat untuk memperkirakan nilai resisnten insulin. Oleh karena itu seseorang dengan nilai IMT , lingkar pinggang, dan Persen lemak tubuh tinggi diharapkan agar merubah gaya hidup yang lebih sehat untuk pencegahan diabetes, penyakit kardiovaskuler dan penyakit metabolik diantaranya untuk usia dewasa dan lanjut usia (Yu Chung, dkk 2017).

\section{Hubungan antara IMT dengan lemak}

\section{Viscelar}

IMT sebagai indikator yang menunjukan status gizi seseorang yang dapat diperoleh dari perhitungan antara tinggi badan dengan berat badan sehingga lemak visceral sebagai komponen tubuh dapat juga mempengaruhi IMT. Beberapa cara yang digunakan mengestimasi gambaran distribusi lemak dalam tubuh adalah dengan mengukur Indeks Masa Tubuh dan persen lemak tubuh serta level lemak Viseral. Hasil analisis Hubungan antara Indeks Masa Tubuh dengan Lemak Viscelar dapat dilihat pada tabel 7.

Berdasarkan uji korelasi Person dihasilkan ada hubungan antara Indek Masa Tubuh dengan lemak Viscelar $(\mathrm{p}=, 000)$. IMT sebagai indikator pengukuran tinggi badan dan berat badan berhubungan dengan lemak visceral karena lemak visceral sebagai salah satu komponen lemak tubuh yang mempengaruhi indeks massa tubuh.

Tabel 7. Lemak Viscelar berdasarkan Indeks Masa Tubuh

\begin{tabular}{lcccc}
\hline $\begin{array}{l}\text { Persen } \\
\text { Lemak } \\
\text { tubuh }\end{array}$ & \multicolumn{3}{c}{ Lemak Viscelar } & \multirow{2}{*}{ Total } \\
\cline { 2 - 4 } Rendah & 1 & 0 & 0 & 1 \\
& $(100 \%)$ & $(0,0 \%)$ & $(0,0 \%)$ & $(100 \%)$ \\
& & & & \\
Normal & Tinggi & $\begin{array}{c}\text { Sangat } \\
\text { Tinggi }\end{array}$ & \\
& 19 & 2 & 0 & 21 \\
& $(90,5 \%)$ & $(9,5 \%)$ & $(0,0 \%)$ & $(100 \%)$ \\
Tinggi & 29 & 1 & 0 & 30 \\
& $(96,7 \%)$ & $(3,3 \%)$ & $(0,0 \%)$ & $(100 \%)$ \\
Sangat & 35 & 18 & 10 & 63 \\
tinggi & $(55,6 \%)$ & $(28,6 \%)$ & $(15,9 \%)$ & $(100 \%)$ \\
\hline Total & 84 & 21 & 10 & 115 \\
& $(73,0 \%)$ & $(18,3 \%)$ & $(8,7 \%)$ & $(100 \%)$ \\
\hline
\end{tabular}

Jika Komponen tubuh mengalami peningkatan, maka proporsi tubuh yang salah satunya adalah lemak visceral juga mengalami peningkatan. Karena lemak visceral sebanyak $45 \%$ mempengaruhi 
massa lemak tubuh. Lemak visceral sendiri berkaitan dengan obesitas yaitu obesitas sentral yang dimana jika terjadi peningkatan akan mengakibatkan resistensi insulin yang dimana sebagai dasar kelainan pada sindrom metabolik. Sindrom metabolik sendiri merupakan kumpulan gejala dan salah satunya dapat menyebabkan resistensi insulin sehingga terjadi diabetes melitus. Visceral fat merupakan akumulasi dari lemak intra abdomen (obesitas sentral) yang tersimpan dibawah kulit lebih dalam dari lemak subkutan. Peningkatan sekresi mediator inflamasi yang terlihat pada lemak viseral pada individu obesitas mencerminkan inflamasi kronis yang sedang berlangsung didalam jaringan lemak individu tersebut., Berat Badan, IMT, Lingkar Pinggang, lemak tubuh, Lemak Viscelar mempunyai hubungan yang bermakna dengan Resisten Insulin (Yu Chung, dkk 2017). Penelitian lain menghasilkan bahwa orang yang obesitas berpeluang 3,36 kali mengalami hipertensi dibandingkan dengan yang tidak mengalami obesitas sentral (Sudijanto, dkk 2007). Ada hubungan antara Indek Masa Tubuh dengan Lemak Viscelar, Terjadinya diabetes melitus tipe 2 sendiri yang berawal dari obesitas yang diukur oleh indeks massa tubuh, sehingga terjadi peningkatan komponen lemak tubuh salah satunya lemak visceral (Hall, dkk 2015).

\section{Kesimpulan}

Hasil penelitian ini jumlah laki-laki sebanyak $35(30,4 \%)$ dan perempuan 80 $(69,6 \%)$, Rata-rata Umur: $(45,14 \pm 14,55)$ tahun, Indeks Masa Tubuh $(25,39 \pm 3,96)$, rata-rata Persen lemak tubuh $(32,63 \pm 6,68)$ rata-rata lemak viscelar $(7,93 \pm 5,13)$. Berdasarkan nilai Indeks Masa Tubuh, berat badan berlebih sebanyak $21(18,3 \%)$ dan obesitas sebanyak 37 (32,2 \%), Persen lemak tubuh kategori tinggi yang tinggi sebanyak $30(26,1 \%)$, dan sangat tinggi sebesar 63 (54,8\%), Lemak Viselar kategori tinggi sebanyak $21(18,3 \%)$ dan sangat tinggi sebanyak $10(8,7 \%)$, ada hubungan antara IMT dengan Persen lemak tubuh $(\mathrm{p}=0,000)$ dan ada hubungan antara IMT dengan lemak Viscelar $(\mathrm{p}=0,000)$

\section{Saran}

1. Tingginya presentase IMT dengan kategori kelebihan berat ban obesitas, persen lemak tubuh kategori sangat tinggi, adanya hubungan IMT dengan lemak tubuh dan lemak viscelar, yang kemungkinan menjadi risiko terjadinya penyakit degenaratif maka perlu diupayakan secara kontinyu pelaksanaan program GERMAS (Gerakan Masyarakat Sehat) terutama peningkatan konsumsi buah dan sayur, aktivitas fisik secara teraratur dan cek kesehatan minimal setiap 6 bulan sekali

\section{KESIMPULAN DAN SARAN}


2. Pelaksanaan GERMAS ini agar diintegrasikan baik secara lintas program maupun lintas sektoral

\section{DAFTAR PUSTAKA}

Bappenas, 2017. Strategi Indonesia terkait Ketenagakerjaan dan Pendidikan, Jakarta

Fatimah, Siti Nur, Ieva B Akbar, Ambrosius Purba, Vita Murniati Tarawan, Gaga Irawan Nugraha, Putri Tessa, Radhiyanti, Titing Nurhayati, 2017. Hubungan Pengukuran Lemak Subutan dengan Indeks Masa Tubuh pada Laki-laki Usia Lanjut, Penelitian Gizi danMakanan, Juni 2017 Vol. 40(1): 29-34

Hall, J.E.; do Carmo, J.M.; da Silva, A.A.; Wang, Z.; Hall, M.E. Obesity-induced hypertension: Interaction of neurohumoral and renal mechanisms. Circ. Res. 2015, 116, 991-1006. [CrossRef] [PubMed

Kementrian Kesehatan, 2020. Peraturan Menteri Kesehatan Republik Indonesia No 21 tahun 2020, tentang Rencana Strategis Kementrian Kesehatan tahun 2020-2024

Kementrian kesehatan RI, 2019. Riset Kesehatan Dasar 2018, Jakarta

Liong Boy Kurniawan, Uleng Bahrun, , Mochammad Hatta, and Mansyur Arif, 2018. Body Mass, Total Body Fat Percentage, and Visceral Fat Level Predict Insulin Resistance Better Than Waist Circumference and Body Mass Index in Healthy Young Male Adults in Indonesia, J. Clin. Med. 2018, 7, 96; doi: $10.3390 / \mathrm{jcm} 7050096$

Nurmalasari, Yesi dan Irma Latifah Hayatuddini, 2017. Hubungan antara Indeks Masa Tubuh dengan Lemak Viscelar pada Pasien Diabetes Melitus Tipe 2 di Poliklinik

Sofa, Ira Maya . 2018. The Incidence of Obesity, Central Obesity, and Excessive Visceral Fat among Elderly Women , Sofa. Amerta Nutr (2018) 228-236 228, DOI : 10.2473/amnt.v2i3.2018.228-236

Sudijanto Kamso, 2007. Dislipidemia dan Obesitas Sentral pada Lanjut Usia di Kota Padang, Jurnal Kesehatan Masyarakat Nasional Vol. 2, No. 2, Oktober 2007

Wiardani, Ni Komang., 2014. Penatalaksanaan Diet Obesitas. Buku Kedokteran EGC, Jakarta

Yu-Chung Tsao, MD a,b,c, I-Shiang Tzeng, PhD d, Hai-Hua Chuang, MD e,WenCheng Li, MDf,g, Tao-Hsin Tung, PhD h,i , Jau-Yuan Chen, MD, 2017.) Body mass index and waist circumference are better predictors of insulin resistance than total body fat percentage in middle-aged and elderly Taiwanese

Zahrok, Siti, Ni Wayan Suarmini. 2020. Peran Perempuan dalam Keluarga. Prosiding SEMATEKSOS 3"Strategi Pembangunan Nasional Menghadapi Revolusi Industri 4.0 